\title{
(-)-DRIMENOL - A VALUABLE STARTING COMPOUND FOR THE SYNTHESIS OF DRIMANIC SESQUITERPENOIDS
}

\author{
Aculina Aricu \\ Institute of Chemistry of the Academy of Sciences of Moldova, Chişinău, \\ MD-2028, 3 Academiei str., Republic of Moldova \\ Tel: +7 (373 2) 739963; Fax: +7 (373 2) 739775;.E-mail:aricu_aculina@yahoo.com
}

\begin{abstract}
Drimenol is a relatively accessible compound, that has been and may be further used as a starting material to prepare sesquiterpenoids. The present review deals with the methods of obtaining of this compound as well as its usage.
\end{abstract}

Keywords: drimenol, albicanol, drimenyl acetate, polygodial, warburganal, synthesis.

\section{Introduction}

Drimenol (1) is a very important reprezentative of drimanic sesquiterpenoids. This terpenol served as a starting compound in the synthesis of diverse natural drimanes [1-5]. According to [1], drimenol (1) has the plant growth regulatory activity comparable with that of heteroauxin.

Besides the South American tree Drimys winteri, drimenol (1) was also found in many other natural sources [1,2]. It has been isolated from some species of the plants of the Warburgia [6] and Porella [7] families, from Polygonum hydropiper [8], Ferula ceratophylla [9] and fungi [10].

The importance of drimenol (1) as a starting compound for the synthesis of drimanic compounds, on the one hand, and the fact that its contents in natural sources is relatively low, on the other hand, have stimulated studies of its synthesis.

In this comunication, the methods of drimenol (1) preparation and the syntheses elaborated on its basis are discussed.

\section{Synthesis of (-)-drimenol and its acetate}

One of the first syntheses of drimenol (1) was accomplished by Wenkert and Strike [11] from dehydroabietic and podocarpic derivatives of type (2) obtained from resin acids. Because of its complexity and a great number of steps $(\sim 25)$, it is not of practical importance.

Pelletier et al. [12] carried out the drimenol (1) synthesis from ambreinolide (3) - the product obtained from a series of available labdanoids [13] (Scheme 1). Dehydrogenation of the ambreinolide (3) with 2,3-dichloro-5,6dicyano-1,4-benzoquinone (DDQ) led to $\Delta^{12}$-dehydroambreinolide (4), whose ozonolysis, followed by reduction of the resulting products with Red-Al, gave (+)-drimane-8 $\alpha, 11$-diol (5). Its monoacetate (6) on successive dehydration with $\mathrm{POCl}_{3}$, and saponification gave the mixture of alcohols (1) and (7) separated by column chromatography on silica gel. The total yield of drimenol (1) in this seven-step synthesis was about $13 \%$.

\section{Scheme 1}

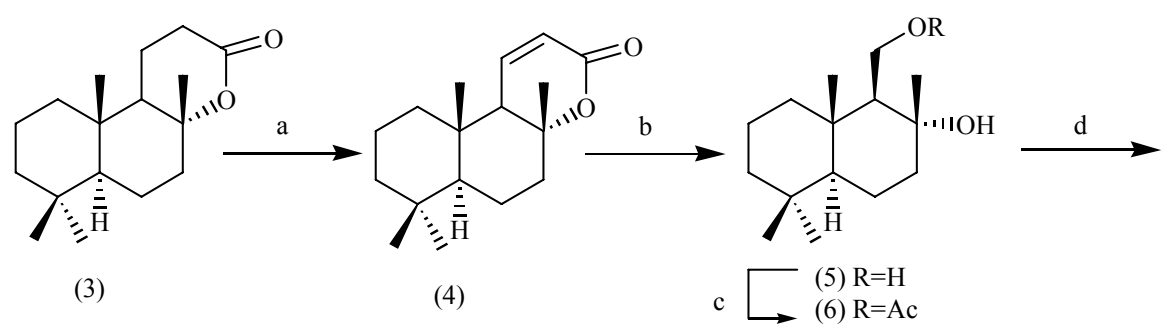

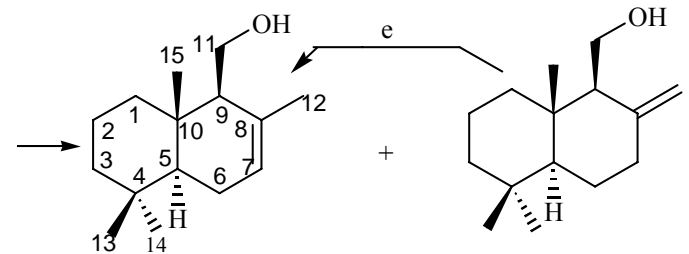

(1)<smiles>CC1(C)CCCC(C)(C)C12CC(=O)c1ccccc12</smiles>

(2)

a) DDQ, dioxane, $\Delta, 40 \%$; b) $\mathrm{O}_{3}, \mathrm{CH}_{2} \mathrm{Cl}_{2},-70^{\circ} \mathrm{C}$; Red- $\mathrm{Al}, \mathrm{C}_{6} \mathrm{H}_{6}, 85 \%$; c) $\mathrm{Ac}_{2} \mathrm{O}, \mathrm{Py}, 92 \%$;

d) $\mathrm{POCl}_{3}, \mathrm{Py} ; \mathrm{KOH}, \mathrm{MeOH}, 53 \%$; e) $\mathrm{BF}_{3} \mathrm{Et}_{2} \mathrm{O}, \mathrm{CH}_{2} \mathrm{Cl}_{2}, 93 \%$. 
It is necessary to mention that authors [14] showed that albicanol (7) isomerizes into drimenol (1) in high yield $(93 \%)$ on treatment with boron trifluoride etherate.

Scheme 2

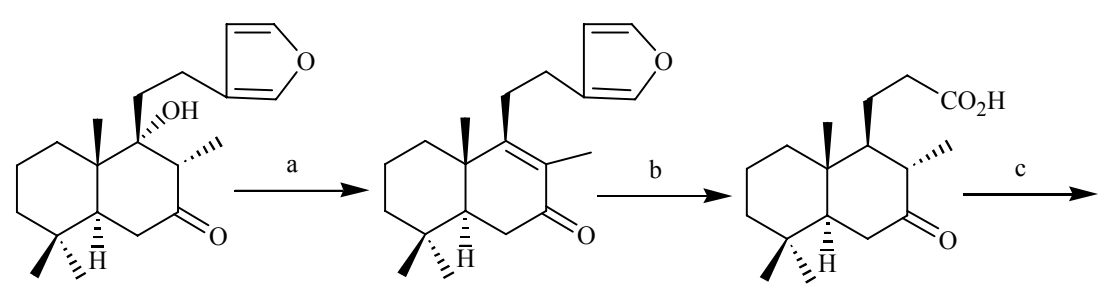

(8)

(9)<smiles>C[C@H]1CCC[C@@H](C)[C@@H](O)C[C@@]12[C@@H](C)CCCC2(C)C</smiles>

(11)

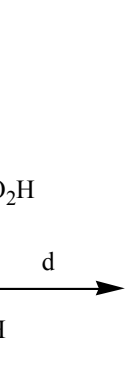$$
\text { - }
$$<smiles>CC1(C)CCCCC1(C)C</smiles>

(12)<smiles>CC1(C)COC2=NC21</smiles><smiles>[2H][C@]12C[C@@H](O)[C@H](C)[C@H](/C=C/C3=NC(C)(C)CO3)[C@]1(C)[C@@H](C)CCC2(C)C</smiles>

(13)<smiles>CC(=O)O[C@H]1C(C)=CC[C@@H]2[C@H](C)[C@@H](C)CC[C@@]12C</smiles>

(14)

(16)

a) $\mathrm{SOCl}_{2}, \mathrm{Py}, 95 \%$; b) $\mathrm{Na}_{2} \mathrm{~S}_{2} \mathrm{O}_{4}, \mathrm{PTC} ; \mathrm{O}_{3}, \mathrm{CH}_{2} \mathrm{Cl}_{2}, \mathrm{MeOH} ; \mathrm{H}_{2} \mathrm{O}_{2}, \mathrm{NaOH}, 80 \%$; c) $\mathrm{NaBH}_{4}, \mathrm{MeOH}, 95 \%$; d) $\left(\mathrm{CH}_{3}\right)_{2} \mathrm{C}\left(\mathrm{NH}_{2}\right) \mathrm{CH}_{2} \mathrm{OH}, \mathrm{H}_{3} \mathrm{BO}_{3}, 85 \%$; e) $\mathrm{PhSeOH}, \mathrm{H}_{2} \mathrm{O}_{2}, 80 \%$;) $\mathrm{O}_{3}, \mathrm{CH}_{2} \mathrm{Cl}_{2}, \mathrm{MeOH} ; \mathrm{CrO}_{3}, \mathrm{H}_{2} \mathrm{SO}_{4}, 75 \%$; g) $\mathrm{NaBH}_{4}, \mathrm{MeOH} ; \mathrm{CH}_{2} \mathrm{~N}_{2}$; h) HMPA, $\Delta$; i) $\mathrm{LiAlH}_{4}$, THF, $80 \%$.

Drimenol (1) was also synthesized from the available labdanoid gispanolone (8) [15] (Scheme 2). The latter was dehydrated into the unsaturated ketone (9), the conjugated double bond of which was reduced, and the resulting product was ozonolyzed giving the keto acid (10). Its reduction with $\mathrm{NaBH}_{4}$ led to a mixture of epimeric hydroxy acids (11) which on interaction with 2-amino-2-methylpropanol-1 afforded a mixture of 4,5-dihydrooxazols (12). This mixture was dehydrogenated with phenyl seleninic acid into a mixture of compounds (13), converted into the keto acid (14) by ozonization and subsequent oxidation of the ozonolysis product by the Jones reagent. Reduction of this keto acid with $\mathrm{NaBH}_{4}$, followed by methylation with $\mathrm{CH}_{2} \mathrm{~N}_{2}$, afforded the hydroxy ester (15). On its heating with HMPA the drimic acid ester (16) has been obtained. Its reduction with $\mathrm{LiAlH}_{4}$ led to drimenol (1). This synthesis of drimenol (1) includes 11 steps, the overall yield being $8 \%$.

Synthesis of drimenol (1) from larixol (17) has been recently described in [16] (Scheme 3). The exocyclic double bond of larixol has been selectively epoxidized with oxone. The obtained epoxy diol (18) was then reduced into triol (19), whose C-6 hydroxy group was selectively acetylated and the resulting compound was cleaved with $\mathrm{OsO}_{4}-\mathrm{NaIO}_{4}$ into the diacetoxy aldehyde (20). This compound was converted into the mixture of the silyl enol eters (21), ozonolysis of which resulted the diacetoxy aldehyde (22). On subsequent heating, compound (22) eliminated acetic acid affording the diene aldehyde (23). Reduction of (23) with $\mathrm{NaBH}_{4}$ gives drimenol (1) as a result of selective 1,4-addition. The overall yield of this eight-step synthesis made up $32.5 \%$.

A short synthesis of the drimenyl acetate (27) was elaborated by Barrero et al. [17] from the sclareol (24) (Scheme 4). Oxidative cleavage of the sclareol (24) side chain by osmic acid and sodium periodate led to the acetoxy aldehyde (25), whose enol silylation gave a mixture of the acetoxy silyl esters (26). On its ozonolysis, followed by reduction of the ozonolysis products with $\mathrm{NaBH}_{4}$, the 11-monoacetate of drimanediol (6) has been formed. On its interaction with $\mathrm{SnCl}_{4}$ the drimenyl acetate (27) was obtained in low yield. The total yield of the desired product in this four-step synthesis was about $17 \%$. 


\section{Scheme 3}<smiles>C=C1C[C@H](O)[C@]2(C)[C@@H](C)CCC[C@]2(C)[C@H]1CCC(C)(C)O</smiles>

(17)

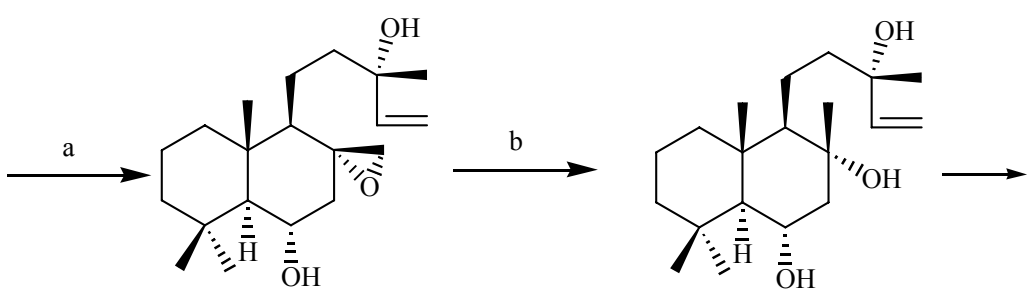

(18)
(19)

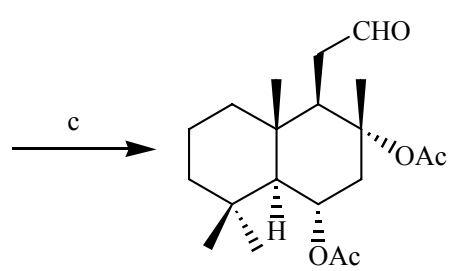

(20)<smiles>CC</smiles><smiles>CC1=C(C=O)[C@]2(C)CCCC(C)(C)[C@@]2(C)C=C1</smiles>

(23)

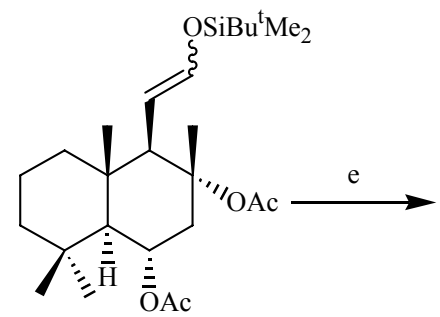

(21)

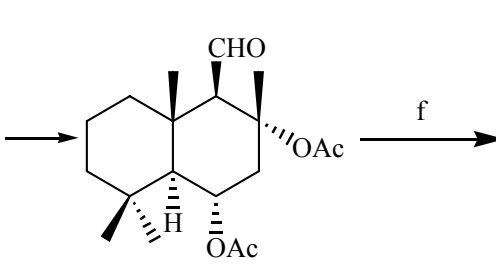

(22)<smiles>CC1=CC[C@]2(C)[C@@H](CO)C(C)=CC[C@]2(C)[C@H]1C</smiles>

(1)

a) oxone, $\mathrm{CH}_{2} \mathrm{Cl}_{2}$, acetone, $\mathrm{H}_{2} \mathrm{O}, \mathrm{NaHCO}_{3}, 18$-crown-6, 81\%; b) $\mathrm{LiAlH}_{4}$, THF, 94\%;

c) $\mathrm{Ac}_{2} \mathrm{O}, \mathrm{Py}, 99 \%$; $\mathrm{OsO}_{4}, \mathrm{NaIO}_{4}, \mathrm{THF}, \mathrm{H}_{2} \mathrm{O}, 84 \%$; d) $\mathrm{Bu}^{\mathrm{t}} \mathrm{Me}_{2} \mathrm{SiCl}, \mathrm{NaH}, \mathrm{THF}, 96 \%$;

e) $\mathrm{O}_{3}, \mathrm{CH}_{2} \mathrm{Cl}_{2}, \mathrm{MeOH},-78^{\circ} \mathrm{C}, \mathrm{Me}_{2} \mathrm{~S}, 78 \%$; f) collidine, $200^{\circ} \mathrm{C}, 77 \%$; g) $\mathrm{NaBH}_{4}, \mathrm{EtOH}, 0^{\circ} \mathrm{C}, 89 \%$.

\section{Scheme 4}<smiles>C=C[C@](C)(O)CCC1[C@@]2(C)CCC[C@@](C)(CC[C@@]1(C)O)C2</smiles>

(24)

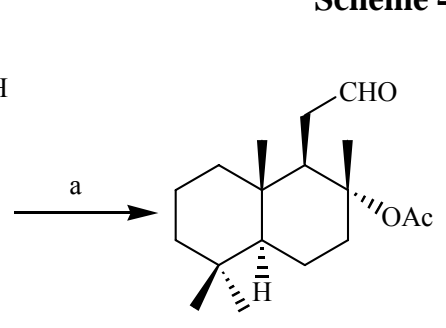

(25)

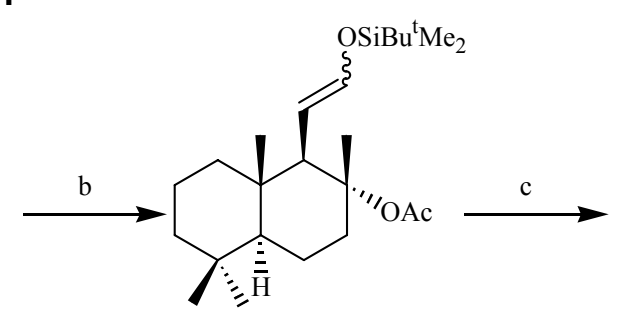

(26)<smiles>CC(=O)OC[C@@H]1C(C)(C)CC[C@]2(C)[C@](C)(O)CCC[C@]12C</smiles>

(6)<smiles>CC(=O)OC[C@H]1C(C)=CC[C@]2(C)[C@@H](C)CCC[C@]12C</smiles>

(27)

a) $\mathrm{OsO}_{4}, \mathrm{NaIO}_{4}, 73 \%$; b) $\mathrm{Bu}^{\mathrm{t}} \mathrm{Me}_{2} \mathrm{SiCl}, \mathrm{NaH}, 99 \%$; c) $\mathrm{O}_{3}, \mathrm{CH}_{2} \mathrm{Cl}_{2}, \mathrm{MeOH},-78^{\circ} \mathrm{C} ; \mathrm{NaBH}_{4}, \mathrm{MeOH}, 95 \%$; d) $\mathrm{SnCl}_{4}, \mathrm{CH}_{2} \mathrm{Cl}_{2}, 25 \%$.

The authors [18] accomplished the drimenol (1) synthesis from sclareol (24) (Scheme 5). This was the first synthesis of a drimanic sesquiterpenoid from a labdanic diterpenoid. This synthesis that correlated these two groups of terpenic compounds firmly confirmed the stereochemistry of drimenol (1). 


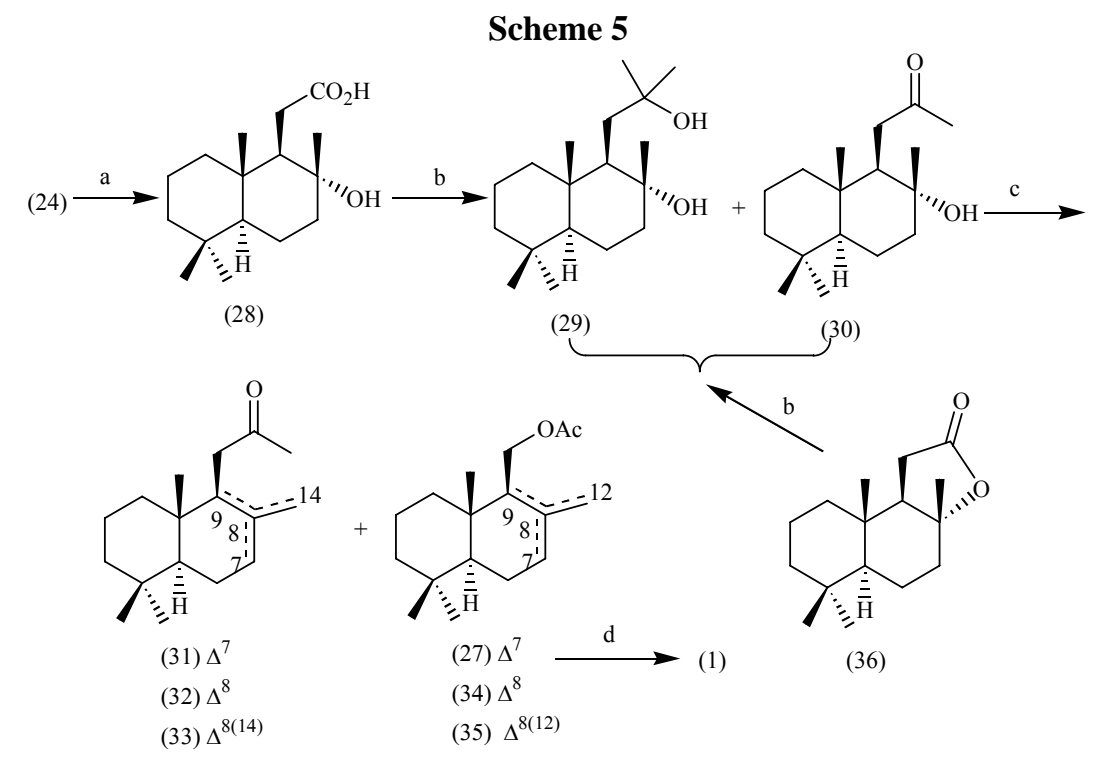

a) $\mathrm{KMnO}_{4}, \mathrm{AcOH}, \mathrm{H}_{2} \mathrm{O}$; $\mathrm{KOH}, \mathrm{MEOH}, \Delta ; \mathrm{H}_{2} \mathrm{SO}_{4}, 92 \%$; b) $\mathrm{CH}_{3} \mathrm{Li}_{2}, \mathrm{Et}_{2} \mathrm{O}, 80 \%$;

c) $\mathrm{H}_{2} \mathrm{O}_{2}, \mathrm{BF}_{3} \cdot \mathrm{Et}_{2} \mathrm{O}$; d) $\mathrm{KOH}, \mathrm{EtOH}, \Delta ., 100 \%$.

Sclareol (24) was oxidized according to the method [19] and the obtained hydroxy acid (28) was introduced in the reaction with methyl lithium. The reaction product was a mixture of the ditertial diol (29) (18\%) and of the hydroxy ketone (30) (80\%). The latter, on interaction with a mixture of concentrated $(93.6 \%)$ hydrogen peroxide and boron trifluoride etherate, afforded a mixture of the unsaturated ketones (31)-(33) and of the isomeric acetoxy drimenes (27), (34) and (35). All these substances were separated and isolated in individual form by column chromatography on $\mathrm{SiO}_{2} \cdot \mathrm{AgNO}_{3}$ and characterized. On saponification of acetate (27), drimenol (1) was obtained. Later it was established [20] that in the reaction with methyl lithium it is possible to use the commercially available norambreinolide (36), a common cleavage product of many labdane diterpenoids. In this case the yield of the hydroxy ketone (30) is a little lower $(65 \%)$, but this reaction is more convenient to carry out. The total yield of drimenol (1) in this synthesis is small $(6.5 \%)$.

It is necessary to note that later on an alternative, shorter synthesis of the hydroxy keton (30) from sclareol (24) was elaborated [21] (Scheme 6). On the ozonolysis of sclareol (24) and subsequent treatment of the ozonolysis products with ammonium chloride, the dimeric product (37) was formed [22]. Its further ozonolysis gave the $\beta$-diketone (38).

\section{Scheme 6}

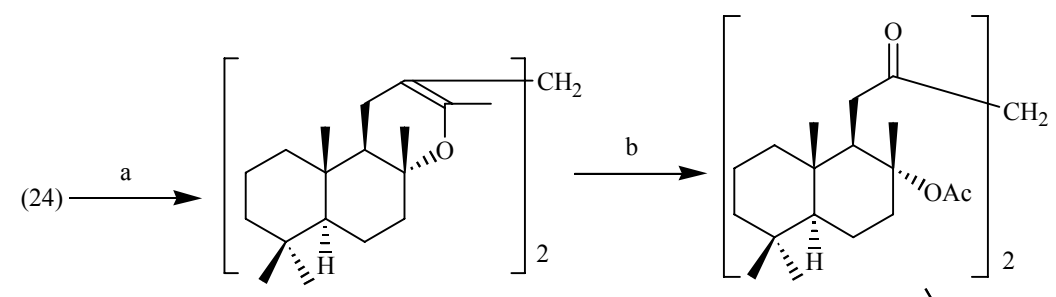

(37)

(38)

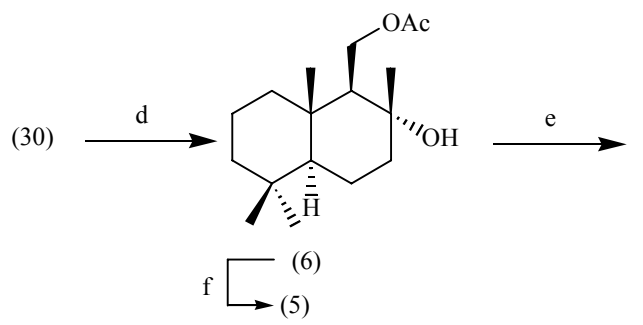<smiles>CC1=CC[C@H]2C(C)(C)CCC[C@]2(C)[C@H]1CO</smiles>

(1)

a) $\mathrm{O}_{3}, \mathrm{MeOH}, 5-10^{\circ} \mathrm{C} ; \mathrm{NH}_{4} \mathrm{Cl}, 80 \%$; b) $\mathrm{O}_{3}$, hexane, $-65 \ldots-70^{\circ} \mathrm{C} ; \mathrm{H}_{2} \mathrm{O}, \Delta, 100 \%$; c) $\mathrm{NaOH}, \mathrm{EtOH}, \Delta$;

d) $\mathrm{H}_{2} \mathrm{O}_{2}, \mathrm{CH}_{2} \mathrm{Cl}_{2},\left(\mathrm{CF}_{3} \mathrm{CO}\right)_{2} \mathrm{O} / \mathrm{NaHCO}_{3}(1: 1), 100 \%$; e) $\mathrm{H}_{2} \mathrm{SO}_{4}$, EtOH, r.t., $56 \%$; f) $\mathrm{KOH}, \mathrm{MeOH}, 98 \%$.

On the treatment of $\beta$-diketone (38) with an alkaline base, the (1:1) mixture of the hydroxy acid (28) and the hydroxy ketone (30) was formed. As a result, this three-step synthesis led to the hydroxy ketone (30) in $37 \%$ overall yield. Furthermore, the hydroxy acid (28) can be converted into (30) as is indicated in scheme 5. 


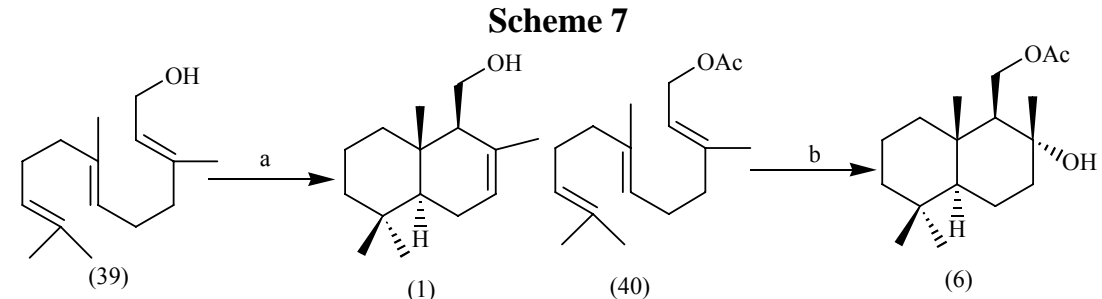

a) 1 mmole $\mathrm{FSO}_{3} \mathrm{H}, \mathrm{C}_{3} \mathrm{H}_{7} \mathrm{NO}_{2},-80 \ldots-85^{\circ} \mathrm{C}, 1 \mathrm{~h}, 71 \%$; b) 10 mmole $\mathrm{FSO}_{3} \mathrm{H},-80 \ldots-85^{\circ} \mathrm{C}, 5 \mathrm{~min}, 77 \%$.

The authors [23] elaborated a highly efficient method for the synthesis of the racemic drimenol (1) and of the hydroxy acetate (6) by the superacidic, low temperature cyclization of E,E-farnesol (39) and its acetate (40), respectively (Scheme 7).

We have investigated the dehydration reaction of monoacetate (6) when treated with a series of dehydrating agents: oxalil chloride in DMSO, TsOH, iodine, oxalic acid, $\mathrm{POCl}_{3}$ [24], $\mathrm{Sc}(\mathrm{OTf})_{3}, \mathrm{CF}_{3} \mathrm{SO}_{3} \mathrm{SiMe}_{3}, \mathrm{PCl}_{5}$, amberlyst-15, $\mathrm{CH}_{3} \mathrm{SO}_{3} \mathrm{SiMe}_{3}$ [25]. Besides, hydroxy acetate (6) was acetilated in diacetate (41), which was pyrolized on heating in the prezence of $\mathrm{SiO}_{2}$ in hexane or in DMSO [26]. In all cases, the reaction afforded mixtures of acetates (27), (34), and (35), which could not be separated by chromatography. Besides these acetates, the drim-7,9(11)-diene (42) was formed as a secondary compound in many cases. On the treatment of the monoacetate (6) with $\mathrm{CF}_{3} \mathrm{SO}_{3} \mathrm{SiMe}_{3}$ in $\mathrm{CH}_{3} \mathrm{CN}$ or with amberlyst-15 in $\mathrm{CH}_{2} \mathrm{Cl}_{2}$ [25], the drim-7,9(11)-diene (42) became the only product of this reaction (Scheme 8). The same results were obtained by the authors [24] and [27].

A good selectivity of the dehydration reaction was reached on the interaction of hydroxy acetate (6) with an excess of $\mathrm{CH}_{3} \mathrm{SO}_{3} \mathrm{SiMe}_{3}$ in $\mathrm{CH}_{3} \mathrm{CN}$ : the yields of drimenil acetate (27) and of diene (42) were 65 and $14 \%$, respectively [25]. This method for the synthesis of drimenil acetate (27) was patented [26]. In most reactions of the hydroxy acetate (6) dehydration, the drimenol acetate (27) dominates.

\section{Scheme 8}

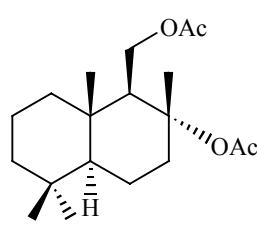

(41)

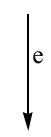

(27)

(34)

(35)<smiles>CC(=O)OC[C@@H]1[C@]2(C)CCC(C)C[C@@]2(C)CC[C@@]1(C)O</smiles>

(6)<smiles>CC1=CC[C@]2(C)C(C)(C)CCC[C@]2(C)[C@H]1CO</smiles>

(1)<smiles>C=C1CC[C@H]2[C@@H](C)CCC[C@]2(C)[C@H]1COC(C)=O</smiles>

(27) $(65 \%)$ $(34)$ (35)

(5)<smiles>C=C1C(C)=CC[C@]2(C)[C@@H](C)CCC[C@]12C</smiles>

(42) $(14 \%)$<smiles>C[C@H]1CCC[C@]2(C)[C@@H](CO)[C@@](C)(O)CC[C@]12C</smiles>

(7)

a) $\mathrm{CH}_{3} \mathrm{SO}_{3} \mathrm{SiMe}_{3}, \mathrm{CH}_{3} \mathrm{CN}, 65 \%$; ; b) $\mathrm{H}_{2} \mathrm{SO}_{4}$, EtOH, 60\%; c) DEAD, $\mathrm{PPh}_{3}, 92 \%$;., d) $\mathrm{AcCl}, \mathrm{C}_{6} \mathrm{H}_{5} \mathrm{NMe}_{2}$;

e) $\mathrm{DMSO}, \mathrm{NaHCO}_{3}, \Delta, 77 \%$.

We have proposed a simple and efficient method for the transformation of monoacetate (6) into the desired drimenol (1) [25]. It was found that treatment of monoacetate (6) with an ethanolic solution of $\mathrm{H}_{2} \mathrm{SO}_{4}$ under mild conditions induced the dehydration accompanied by deacetylation to give a crystalline product that was a mixture of drimenol (1) and albicanol (7) at $10: 1$ ratio formed in a (60\%) overall yield. Recrystallization of this mixture from hexane gave pure drimenol (1) (56\%) [28].

It should be mentioned that recently Spanish chemists [29] have synthesized drimenol (1) in a high yield (92\%) on the treatment of driman-8 $\alpha, 11$-diol (5) with dietilazadecarboxilat (DEAD) and trifenil phosphine in $\mathrm{C}_{6} \mathrm{H}_{6}(\mathrm{Scheme} 8)$.

\section{The synthesis of drimanic sesquiterpenoids on the basis of drimenol (1)}

\subsection{The synthesis of the drimanic aldehydes}

The synthesis of the drimane dialdehyde polygodial (43) was carried out starting with drimenol (1) (Scheme 9). According to [30], drimenol (1) was oxidized into drimenal (44), the aldehyde group of which was protected and compound (45) was oxidized into aldehyde (46) with selenium dioxide. The treatment of aldehyde (46) with p-toluene sulfonic acid gave the target polygodial (43) (30\% overall yield), isolated earlier from some plants and marine organisms $[1,2]$. 
According to the synthesis [31], drimenol (1) was acetylated and its acetate (27) was oxidized with selenium dioxide into the hydroxy acetates (47) in a $45 \%$ yield. If the oxidation of drimenyl acetate was carried out with a catalytic amount of $\mathrm{SeO}_{2}$ in the presence of bis(4- metoxifenol) selenoxide as a co-oxidant gives, apart from compound (47) (60\%), a small amount of 11-acetoxydrim-7-en-12-ol (48) (30\%) . high yield.

Saponification of the latter gave diol (49) which was oxidized by the Swern reagent into polygodial (43) in

The particular interest of researchers in polygodial can be explained by its various biological activities: antifeedant [32, 33], antibacterial [7, 34], cytotoxic [7, 35], allergenic [7], piscicidal, molluscicidal, anticomplemental, and plant-growth regulatory $[1,2]$.

\section{Scheme 9}<smiles>CC(=O)OC[C@H]1C(C)=CC[C@]2(C)[C@@H](C)CCC[C@]12C</smiles>

(27)<smiles>CC(C)COC[C@]1(O)C(CO)=CC[C@H]2C(C)(C)CCC[C@@]21C</smiles>

(47) $(60 \%)$<smiles>CC(=O)OC[C@H]1C(CO)=CC[C@]2(C)[C@@H](C)CCC[C@]12C</smiles>

$(48)(30 \%)$<smiles>CC1(C)CC[C@]2(C)[C@@]1(C)CC[C@]1(C)[C@@H](CO)C(CO)=CC[C@]12C</smiles>

(49)

a) $\mathrm{PCC}, \mathrm{CH}_{2} \mathrm{Cl}_{2}, 75 \%$; b) $\mathrm{CH}\left(\mathrm{CH}_{2} \mathrm{OH}\right)_{2}, \mathrm{H}^{+}, 88 \%$; c) $\mathrm{SeO}_{2}$ (cat), (p- $\left.\mathrm{MeOC}_{6} \mathrm{H}_{4}\right)_{2} \mathrm{SeO}, 45 \%$;

d) $\mathrm{TsOH}$, acetone, $100 \%$; e) $\mathrm{Ac}_{2} \mathrm{O}, \mathrm{Py}, 98 \%$; f) $\mathrm{K}_{2} \mathrm{CO}_{3}, \mathrm{MeOH}, 100 \%$; g) $(\mathrm{COCl})_{2}$, DMSO, $98 \%$.

The hydroxy acetate (47) has been used as a starting compound for the synthesis of another drimanic dialdehyde, warburganal (50), that is similar to polygodial (43) in the variety and level of biological activities [36] (Scheme 10).

\section{Scheme 10}

(47)

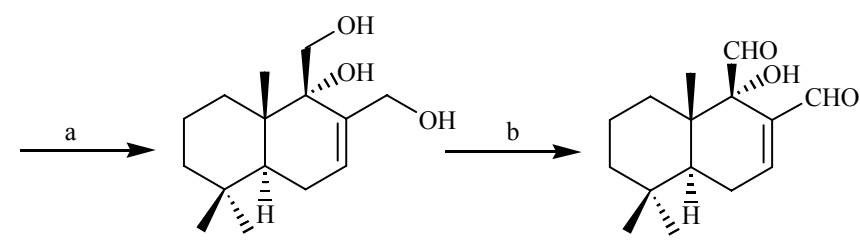

(51)

(50)

a) $\mathrm{KOH}, \mathrm{MeOH}, 100 \%$; b) DMSO, $\left(\mathrm{CF}_{3} \mathrm{CO}\right)_{2} \mathrm{O}, 64 \%$.

Compound (47) was saponified into triol (51) which, on oxidation with DMSO and $\left(\mathrm{CF}_{3} \mathrm{CO}\right)_{2} \mathrm{O}$, gave the final product (50) in high yield.

Cinnamodial (52) was obtained from drimenol (1) in 13 steps in $10 \%$ overall yield. The diol (59) was synthesized from drimenol (1) according to the method [37], and further synthesis was continued as described in [38] (Scheme 11). Its acetate (60) has been successively subjected to oxidation with selenium reagents and to selective saponification giving acetoxy triol (62) that oxidizes with Swern's reagent into cinnamodial (52). 


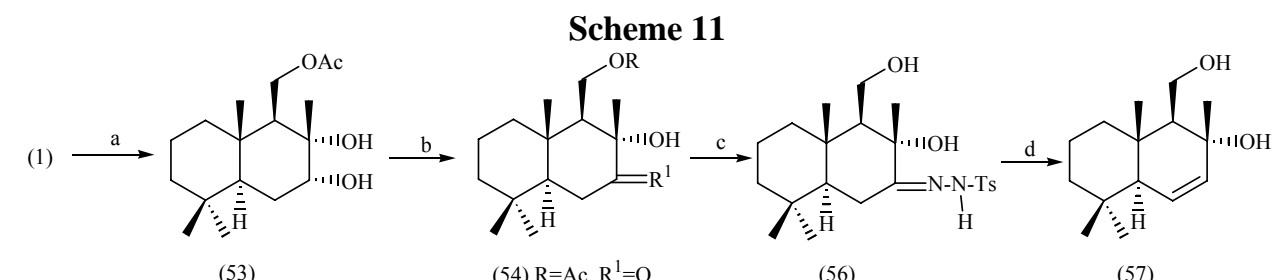

(53)

(54) $\mathrm{R}=\mathrm{Ac}, \mathrm{R}^{1}=\mathrm{O}$

(55) $\mathrm{R}=\mathrm{H}, \mathrm{R}^{1}=\mathrm{O}$

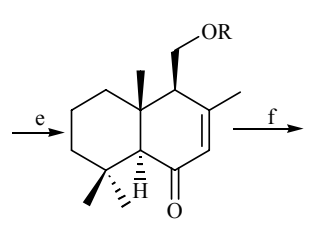

(58)

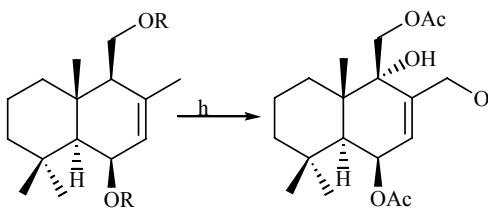

(61)

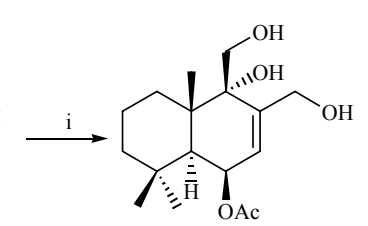

(62)

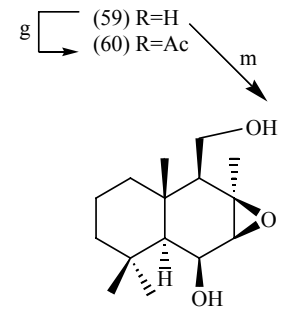

(63)<smiles>CC(=O)O[C@H]1C=C(C=O)[C@@](C)(O)[C@@]2(C)CCCC(C)(C)[C@]12C</smiles>

(52)

a) $\mathrm{Ac}_{2} \mathrm{O} / \mathrm{Py} ; \mathrm{OsO}_{4}, \mathrm{NMO}, 56 \%$; b) NBS, $\mathrm{CH}_{2} \mathrm{Cl}_{2} ; \mathrm{KOH}, \mathrm{MeOH}, 90 \%$; c) $\mathrm{TsNHNH}_{2}, \mathrm{BF}_{3} \mathrm{Et}_{2} \mathrm{O}, \mathrm{C}_{6} \mathrm{H}_{6}$;

d) BuLi, THF, 91\%; e) $\mathrm{Ac}_{2} \mathrm{O}$, Py; PCC; f) DIBAL, THF;, $100 \%$; g) $\mathrm{Ac}_{2} \mathrm{O}$, Py, DMAP;

h) $\mathrm{SeO}_{2}$ (cat), (p-MeOC $\left.\mathrm{H}_{4}\right)_{2} \mathrm{SeO}$, dioxane; i) $\mathrm{K}_{2} \mathrm{CO}_{3}, \mathrm{MeOH}$; l) $(\mathrm{COCl})_{2}$, DMSO; m) m-CPBA, $\mathrm{CH}_{2} \mathrm{Cl}_{2}, 95 \%$.

Drimenol (1) has been also used as a starting material for the preparation of uvidin $\mathrm{C}$ (63), metabolite of fungi Lactarius uvidus Fries [39]. By acetylation and dihydroxylation of drimenol (1), compound (53) was obtained in an overall yield of 56\%. Oxidation of (53) with N-bromosuccinimide afforded ketol (54) in good yield. Saponification of (54) followed by treatment of the resulting diol (55) with tosylhydrazide gave compound (56). Tosyl hydrazone (56) was converted to the allylic alcohol (57) in 91\% yield. Acetylation of (57) and subsequent oxidative rearrangement with pyridinium chlorocromate gave enone (58). Reduction of (58) with DIBAL afforded the allylic alcohol (59) in quantitative yield. The treatment of (59) with m-chloroperbenzoic acid afforded uvidin C (63) in 95\% yield.

\subsection{The synthesis of drimanic ketones}

Starting from drimenol (1), Swedish chemists [40] accomplished the synthesis of drim-8-en-7-one (64), thus confirming its structure and stereochemistry (Scheme 12). 7 $\alpha, 8$-Epoxidriman-11-ol (65), preparation by epoxidation of drimenyl acetate, was converted in good yield to drim-8-en-7 $\alpha$-11-diol (68) in three steps. These were performed in situ and involved oxidation to the epoxyaldehide (66) followed by base-catalyzed isomerization to the conjugated aldehyde (67). Acetylation of the diol (68) at low temperature furnished 11-acetoxydrim-8-en-7 $\alpha$-ol (69) as the major product which on oxidation with the Jones reagent yielded keto ester (70). Hydrogenolysis of the conjugated keto ester (70) applying zinc in acetic acid gave drim-8-en-7-one (64) in excellent yield.

\section{Schema 12}

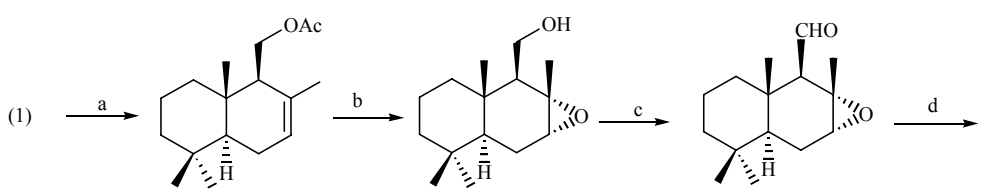

(27)

(66)<smiles>CC1=C(C)C(C)C2(C)CCCCC2(C)C1</smiles>

(67)

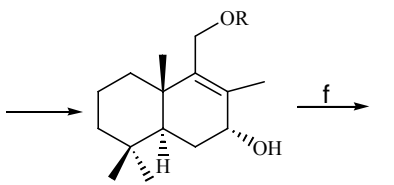

(68) $\mathrm{R}=\mathrm{H}$

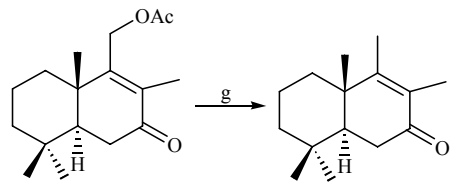

(70)

(64) a) $\mathrm{Ac}_{2} \mathrm{O}, \mathrm{Py}, 100 \%$; b) m-CPBA, $\mathrm{CH}_{2} \mathrm{Cl}_{2} ; \mathrm{KOH}, \mathrm{MeOH}, 80 \%$; c) $\mathrm{CrO}_{3}, \mathrm{Et}_{2} \mathrm{O}, 100 \%$;

d) $\mathrm{KOH}, \mathrm{MeOH} ; \mathrm{NaBH}_{4}, \mathrm{MeOH}, 82 \%$; e) $\mathrm{Ac}_{2} \mathrm{O}$, Py; f) Jones reagent, $78 \%$; g) $\mathrm{Zn}, \mathrm{AcOH}, 100 \%$. 


\subsection{The synthesis of the drimanic alcohols}

We studied the reaction of drimenol (1) with $\mathrm{SeO}_{2}$ in order to perform further functionalization of compound (1) [24]. Refluxing of alcohol (1) with $\mathrm{SeO}_{2}$ in ethanol gives known diols (71) and (49) and the new compound (72) (Scheme13), the structure of which was established based on the spectral data. Under the optimal conditions, the yield of the reaction products (71) and (49) was 44 and 8\%, respectively. It should be mentioned that diols (71) and (49) are the known precursors of biologically active drimanes, warburganal (50) and poligodial (43) [2, 4, 41, 42, 43] natural compounds possessing a wide range of biological activities, and of other natural drimanes [44].<smiles>CC1=CC[C@@]2(C)[C@H](CO)C(C)=CC[C@]2(C)[C@H]1CO</smiles>

(1)
(71) $(44 \%)$<smiles>CC1(C)CCC[C@@]2(C)[C@H](CO)C(CO)=CC[C@]12C</smiles>

(49) $(7 \%)$<smiles>CCO[C@H]1C[C@H]2C(C)(C)CCC[C@]2(C)C(CO)=C1C</smiles>

(72)<smiles>CC1(C)CCC[C@@]2(C)[C@](C)(O)C(C=O)=CC[C@]12C</smiles>

(50)<smiles>C[C@H]1CCC[C@]2(C)[C@H](C=O)C=CC[C@H]12</smiles>

(43)

a) $\mathrm{SeO}_{2}, \mathrm{EtOH}, \Delta$;

The (-)-ent-drim-9(11)-en 8 $\alpha$-ol (73) and its dextrorotatory C(8)- epimer (74) [45] (Scheme14) were isolated from the culture filtrate of the fungi Aspergillus oryzae used in breadmaking and in the production of some beverages in Japan. The structure of these drimanic compounds was confirmed on the basis of the spectral data and synthesis of racemic alcohols. But its stereochemistry remains unknown.

To determine the absolute configuration of compounds (73) and (74), we [46] carried out the stereoselective synthesis of compound (75) from sclareol (24) (Scheme 14). Sclareol (24) was transformed in its diacetate (76). A detailed investigation of its reactions with different oxidants was carried out [46]. However, either the reaction did not occur or the yeld of the expected product (77) was low (25\%). A reasonable yield of acetoxy ketone (77) (52\%) was obtained on decomposition of the ozonolysis products of sclareol diacetate (76) on heating with $\mathrm{Cu}(\mathrm{OAc})_{2} \cdot \mathrm{H}_{2} \mathrm{O}$ in toluene.

To prepare $8 \alpha$-acetoxydrim-9(11)-ene (75), acetoxy ketone (77) was subjected to photolytic cleavage according to the Norrish II reaction. The reaction product was saponified giving the dextrorotatory compound (75). This result proves that the natural products (73) and (74) belong to the enantiomeric series (Scheme14). It should be noted that this reaction has also been studied by Spanish chemists [47], and drim-7,9(11)-diene (42) has been isolated as the only reaction product. This result was difficult to explain and we suggested that the primary reaction product, unsaturated acetate (78), decomposes during chromatography on $\mathrm{SiO}_{2}$.<smiles>C=C1[C@@]2(C)CCC[C@H](C)[C@@H]2CC[C@@]1(C)O</smiles>

(73)<smiles>C=C1CC[C@@](C)(O)C(=C)[C@H]2CCCC[C@]12C</smiles>

(74)

\section{Schema 14}

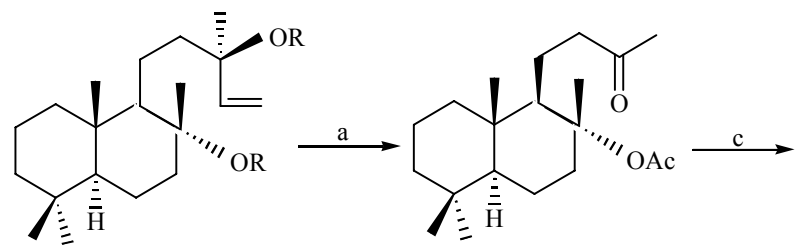

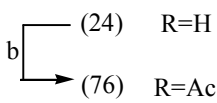<smiles>C=C1[C@@]2(C)CCC[C@H](C)[C@@H]2CC[C@@]1(C)OC(C)=O</smiles>

(78)

a) $1 . \mathrm{O}_{3}, 2 . \mathrm{Cu}(\mathrm{OAc})_{2} \mathrm{H}_{2} \mathrm{O}, 52 \%$; b) AcCl, $\mathrm{C}_{6} \mathrm{H}_{5} \mathrm{NMe}_{2}, 80 \%$; c) 1. hv/hexan, 2. $\mathrm{KOH} / \mathrm{EtOH}, 44 \%$. 
Later on, we elaborated an alternative route for preparation of drim-9(11)-en-8 $\alpha$-ol (75) and its epimer (79) starting from drimenol (1) [48].

Oxidation of drimenol (1) by the Swern reagent or DMSO and $\mathrm{P}_{2} \mathrm{O}_{5}$ produced the known aldehyde drimenal (43) in yields of 94 and 95\%, respectively. We note that the method using $\mathrm{P}_{2} \mathrm{O}_{5}$ is more convenient because the reaction occurs at ambient temperature whereas oxidation by Swern's reagent occurs at $-60^{\circ} \mathrm{C}$. Previously, drimenal (43) was prepared through oxidation of drimenol (1) by pyridinium chlorochromate ( $\mathrm{PCC})\left(75 \%\right.$ yield) or $\mathrm{CrO}_{3}$ in pyridine (30\% yield). At the next step, compound (43) was isomerized into the known isodrimenal (80). Isodrimenal was reduced by $\mathrm{NaBH}_{4}$ into isodrimenol (81). Reaction of alcohol (81) with $m$-chloroperbenzoic acid afforded a liquid mixture of the known 8,9 $\alpha$-(82) and 8,9 $\beta$-(83)-epoxydriman-11-ols at a 3.4:1 ratio. The mixture of compounds (82) and (83) was used without separation in the next step. There reaction with $p$-tosyl chloride in Py gave the mixture of epoxy tosylates (84) and (85) in a good yield. Subsequent reaction of the mixture of (84) and (85), first on heating with $\mathrm{KI}$ in an acetone:DMF mixture, and then with $\mathrm{Ph}_{3} \mathrm{P}$, afforded a mixture of drim-9(11)-en-8 $\alpha$-ol (75) and drim-9(11)-en-8 $\beta$-ol (79) at a 2.5:1 ratio and in 60\% overall yield. The mixture was separated by chromatography. Compounds (75) and (79) were identified by comparing their physicochemical and spectral properties with the published data. Thus, drim-9(11)-en-8-ols (75) and (79) were synthesized from drimenol (1) in six steps in $\sim 26 \%$ overall yield (Scheme 15).

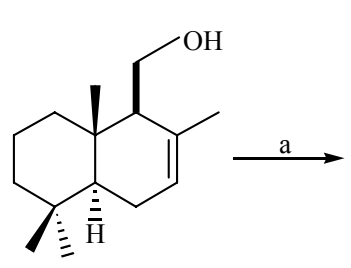

(1)<smiles>CC1=CC[C@H]2[C@@H](C)CCC[C@]2(C)C1C=O</smiles>

(43)

\section{Scheme 15}

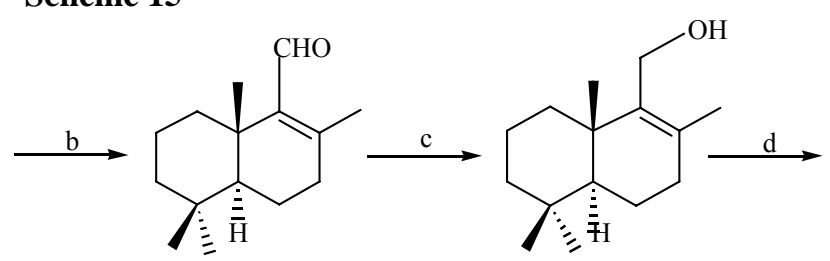

(80)

(81)<smiles>C[C@H]1CC[C@](C)(CO)[C@@]2(CO)[C@@H](C)CCC[C@]12C</smiles>

(82) 8,9 - $\alpha$-epoxi

(83) 8,9- $\beta$-epoxi

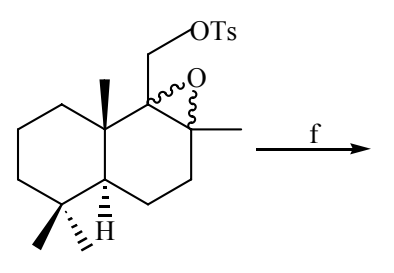

(84) 8,9 - $\alpha$-epoxi

(85) $8,9-\beta$-epoxi<smiles>C=C1[C@@]2(C)CCC[C@H](C)[C@@H]2CC[C@@]1(C)O</smiles>

(75)<smiles>C=C1[C@@]2(C)CCC[C@H](C)[C@@]2(C)CC[C@@]1(C)O</smiles>

(79)

a) $\mathrm{P}_{2} \mathrm{O}_{5}, \mathrm{DMSO}, 95 \%$; b) TsOH, $\mathrm{C}_{6} \mathrm{H}_{6}, \Delta, 82 \%$; c) $\mathrm{NaBH}_{4}, \mathrm{EtOH}, 75 \%$; d) mCPBA, $\mathrm{CH}_{2} \mathrm{Cl}_{2}, 95 \%$; e) pTsCl, Py, 77\%; f) 1.KI, DFA, 2. $\mathrm{Ph}_{3} \mathrm{H}, 60 \%$.

\section{Conclusion}

The data mentioned above demonstrated that drimenol (1) proves to be a valuable and convenient compound for the synthesis of various natural drimanes including those with biological activities.

\section{References}

[1]. Jansen, B. J. M.; de Groot, A. Nat.Prod. Rep., 1991, 8, Nr. 3, 309-318.

[2]. Jansen, B. J. M.; De Groot, A. Nat. Prod. Rep., 2004, 21, Nr. 4, 449-477.

[3]. Jansen, B. J. M.; de Groot, A. Nat. Prod. Rep., 1991, 8, Nr. 3, 319-337.

[4]. Влад, П. Ф.; Колца, М. Н.; Миронов, Г. Н. Изв. АН, сер. хим., 1997, 46, № 5, 896-913.

[5]. Vlad, P.F. In Studies in Natural Products Chemistry, Bioactive Natural Products (Part M), Atta-ur Rahman /Editor, Elsevier, Amsterdam, 2006, 33, 393-432.

[6]. Brooks, C .J .W; Draffan, G. H. Tetrahedron, 1969, 25, 2865-2885; Kioy, D.; Gray, A. I.; Waterman, P. G. Phytochemistry, 1990, 29, 3535-3538.

[7]. Asakawa, Y.; Toyota, M; Takemoto, T. Phytochemistry, 1978, 17, 457-460.

[8]. Fukuyama, Y.; Sato, T.; Asakawa, Y.; Takemoto, T. Phytochemistry, 1982, 21, 2895-2898.

[9]. Dembitskii, A. D.; Crotova, G. I.; Zamcova, V. V. Izv. Acad. Nauk Kaz. SSR, ser. khim., 1991, № 6, 63-65.; Fraga, B. M. Natur. Prod. Rep., 1995, 12, 303-321.

[10]. De Bernardi, M.; Mellerio, G.; Vidari, G.; Vita-Finzi, P. J. Chem. Soc., Perkin Trans. 1, 1980, $221-226$. 
[11]. Wenkert, E.; Strike, D. P. J.Am. Chem. Soc., 1964, 86, 2044-2050.

[12]. Pelletier, S.W.; Lajsic, S.; Ohtsuka, Y.; Djarmati, Z. J. Org. Chem., 1975, 40, 1607-1609.

[13]. Vlad, P. F.; Koltsa, M. N. Synthesis and Application of Odorous Compounds from Labdane Diterpenoids, Kishinev, Shtiintsa, 1988 (in Russian).

[14]. Akita, H.; Nozawa, M.; Mitsuda, A.; Ohsawa, H. Tetrahedron Asymmetry, 2000, 11, 1375-1388.

[15]. Hueso-Rodriguez, J. A.; Dominguez, G.; Rodriguez, B. An. Quim., ser C, 1988, 84, 215-218.

[16]. Lagnel, B. M. F.; Morin, C.; De Groot, A. Synthesis, 2000, 1907-1916.

[17]. Barrero, A. F.; Manzaneda, E. A.; Altarejos, J.; Salido, S; Ramos, J. M. Tetrahedron Lett., 1994, 35, 29452948.

[18]. Vlad, P. F.; Kryshtal, G. V.; Lazurievskii, G. V. Zh. Obshch. Khim., 1967, 37, 2187-2190.

[19]. Schumacher, J. N. ; Henley, W. M.; Teague, C. E. US Patent 3050532.

[20]. Kuchkova, K. I.; Chumakov, Y. M.; Simonov, Y. A.; Bocelli, G.; Panasenco, A. A.; Vlad, P. F. Synthesis, 1997, 1045-1048.

[21]. Aricu, A. N.; Koltsa, M.N.; Vlad, P. F.; Kukovinets, O. S.; Odinokov, V. N.; Tolstikov, G. A. Khim. Prirod. Soedin, (Chem. Nat. Comp.), 1991, 343-349.

[22]. Odinokov, V. N.; Vlad, P. F.; Kukovinets, O. S.; Isakova, L. A.; Lindeman, S. V.; Struchkov, Yu. T.; Tolstikov, G. A. Dokl. Akad. Nauk SSSR, 1983, 269, 853-855.

[23]. Vlad, P.F.; Ungur, N. D.; Perutsky, V. B. Khim. Prirod. Soedin, (Chem. Nat. Comp.), 1986, 793; Vlad, P. F. Pure Appl. Chem., 1993, 65,1329-1336; Polovinca, M. P.; Korchagina, D.V.; Gatilov, Y. G.; Bagrianskaya, I. Y.; Barkhash, V. A.; Shcherbukhin, V. V.; Zefirov, N. S.; Perutskii, V. B.; Ungur, N. D.; Vlad, P. F. J. Org. Chem., 1994, 59, 1509-1517; Vlad, P. F.; Ungur, N. D.; Hung, N. V.; Perutsky, V.B. Russ. Chem. Bull. (Engl. Transl.), 1995, 44, 2390-2403.

[24]. Кучкова, К. И.; Арыку, А. Н.; Драгалин, И. П.; Влад, П. Ф. Изв. АН, сер. хим., 2004, № 12, $2745-2748$.

[25]. Кучкова, К. И.; Арыку, А. Н.; Барба, А. Н.; Влад, П.Ф. Химия природ. соедин., 2007, №4, с. $340-343$.

[26]. Vlad, P; Cucicova, C.; Arîcu, A.; Barba, A. Brevet de invenție a Republicii Moldova Nr. 3273. Data publicării hotărârii de acordare a brevetului 31.03.2007, BOPI, 2007, Nr. 3.

[27]. Poigny, S.; Huor, T.; Guyot, M.; Samadi, M. J. Org. Chem, 1999, 64, 9318-9320.

[28]. Vlad, P.; Cucicova, C.; Arîcu, A. Brevet de invenție a Republicii Moldova Nr. 2018. Data publicării hotărârii de acordare a brevetului 31.10.2002, BOPI, 2002, Nr. 10.

[29]. Alvarez-Manzaneda, E.J.; Chahboun, R.; Barranco Perez, I.; Cabrera, E.; Alvarez, E.; Alvarez-Manzaneda, R. Organic Lett., 2005, 7, Nr.8, 1477-1480.

[30]. Cortes, M.J.; Razmilic, I.; Sierra, J.R.; Lopez, J.; Chem.Ind., 1985, 735.

[31]. Razmilic, J.; Lopez, J.; Sierra, J.; Cortes, M. Synth. Commun., 1987, 17, 95-103.

[32]. Kubo, I.; Lee, Y. W.; Pettei, M.; Pilkiewicz, F.; Nakanishi, K. J. Chem. Soc., Chem. Commun, $1976,1013-1014$.

[33]. Caproli, V.; Cimino, G.; Colla, R.; Gavagnin, M.; Sodano, G.; Spinella, A. J. Nat. Prod., 1987, 50, $146-151$.

[34]. Paul, V. J.; Seo, Y.; Cho, K. W.; Rho, J. R.; Shin, J.; Bergguist, P. R. J. Nat. Prod., 1997, 60, $1116-1120$.

[35]. Banthorpe, D. V.; Brooks, C. J. W.; Brown, J. T.; Leppin, G. J.; Morris, G. S. Phytochemistry, 1989, 28, 16311633.

[36]. Oyarzum, M. L.; Cortes, M.; Sierra, J. Synth. Commun., 1982, 12, 951-958.

[37]. Lopez, J.; Sierra, J.; Cortes, M. Chem. Lett., 1986, 2073-2074.

[38]. Cortes, M.; Razmilic, I.; Lopez, J. J. Nat. Prod., 1990, 53, 1369-1371.

[39]. De Bernardi, M.; Mellerio, G.; Vidari, G.; Vita-Finzi, P. J. Chem. Soc., Perkin Trans. 1, 1983, $2739-2743$.

[40]. Aasen, A. J.; Vogt, C. H. G.; Enzell, C. R. Acta Chem. Scand., 1975, B29, 51-55.

[41]. Barrero, A. F.; Cortes, M.; Marzaneda, E. A.; Cabrera, E.; Chahboun, R.; Lara, M.; Rivas, A. R. J. Nat. Prod., 1999, 62, Nr.11, 1488-1491.

[42]. Urones, J. G.; Marcos, J. S.; Perez, B. G.; Diez, D.; Lithgow, A. M.; Gomes, P. M.; Basabe, P.; Garrido, N.M. Tetrahedron, 1994, 50, Nr. 37, $10995-11012$.

[43]. Razmilic, I.; Lopez, J.; Sierra, J.; Cortés, M. Synth. Commun, 1987, 17, 95-103.

[44]. Hollinshead, D.M.; Howell, S.C.; Ley, S.V.; Mahon, M.; Ratcligffe, N.M.; Worthington, P.A. J. Chem. Soc., Perkin. Trans. I, 1983, $1579-1589$.

[45]. Wada, K.; Tanaka, S.; Marubo, S. Agric. Biol. Chem., 1983, 47, 1075 - 1078.

[46]. Влад, П. Ф.; Арыку, А. Н.; Чокырлан, А. Г. Изв. АН, сер. хим. 2003, № 2, 423-426.

[47]. Lithgow, A.M.; Marcos, J.S.; Basabe, P.; Sexmero, J.; Diez, D.; Gomez, A.; Estrella, A.; Urones, J. G. Natur. Prod. Lett., 1995, 6, Nr.4, 291-294.

[48]. Кучкова, К.И.; Арыку, А.Н.; Драгалин, И.П.; Влад, П.Ф. Химия природ. соед., 2005, № 2, 152-155. 